\title{
Germ-line chimaeras can produce both strains of fowl with high efficiency after partial sterilization
}

\author{
L. Vick, G. Luke and K. Simkiss* \\ Department of Pure and Applied Zoology, University of Reading, Reading RG6 2AJ, UK
}

\begin{abstract}
The drug busulphan is known to be cytotoxic to migrating primordial germ cells (PGCs). A technique is described in which doses of $0,25,50$ and $250 \mu \mathrm{g}$ busulphan in $40 \mu \mathrm{l}$ sesame oil were injected into the yolk of White Leghorn eggs incubated for $0,24,48$ and $72 \mathrm{~h}$. The percentage survival values of these embryos showed that the older the embryo at the time of injection, the greater the survival. Increasing the dose of busulphan decreased the survival. The percentage of embryos showing abnormalities increased with higher doses of busulphan. The number of germ cells in histological sections from gonads of 16-day embryos was estimated and in embryos treated with $50 \mu \mathrm{g}$ and $250 \mu \mathrm{g}$ busulphan the number of germ cells was significantly less than in the controls. Eggs were injected with $50 \mu \mathrm{g}$ busulphan at $24-30 \mathrm{~h}$, and at $50-55 \mathrm{~h}$ the embryos received an intravascular injection of a germinal crescent cell suspension containing PGCs from Rhode Island Red embryos. Twenty hatchlings from these experiments were raised to sexual maturity. All these birds were fertile and half of the breeding groups producing offspring from the transferred germ cells at a rate of about $35 \%$ of the total. The technique would improve the efficiency of producing transgenic gametes.
\end{abstract}

\section{Introduction}

The characteristically large and yolky egg of the bird has led to considerable technical difficulties in producing transgenic offspring. The usual technique of microinjection of foreign DNA into the pronuclei of the fertilized egg is very successful in mice (Palmiter $e$ t al., 1982) but the inability to localize these structures in the cytoplasm of the avian egg has meant that this approach has not yet been successful in birds (Sang and Perry, 1989). As a result, most of the work on birds has concentrated on manipulating either undifferentiated stem cells (Petitte et al., 1990) or primordial germ cells (Simkiss et al., 1990). These two approaches rely upon introducing foreign DNA into a cell line that will eventually produce gametes and thus transgenic offspring.

It has been shown that it is possible to introduce foreign genes into avian primordial germ cells (PGCs) by means of defective retroviruses (Savva et al., 1991). These transfected cells become incorporated into the gonads. Thus, by using donor PGCs that are injected into recipient embryos, it is possible to produce offspring with chimaeric gonads (Simkiss $e t$ al., 1989). Male offspring from such experiments contain the foreign DNA in their spermatozoa and produce transgenic offspring (Vick et al., 1993).

The percentage of transgenic offspring produced by this method is clearly related to the ratio of the number of transfected PGCs that are injected from the donor embryo in relation to the number that are produced endogenously by the recipient embryo. Thus, providing the manipulated cells behave like normal PGCs, the ratio of transfected donor PGCs $\left(N_{\mathrm{D}}\right)$ to recipient PGCs $\left(N_{R}\right)$ will determine the relative numbers of spermatozoa or ova carrying the foreign DNA. For these reasons there has been considerable interest in methods for destroying PGCs in avian embryos. Three types of approach have been adopted. The first, involving physical removal or interference with PGC migration (McCarrey and Abbott 1982), is too damaging to enable the production of normal hatchlings. The second approach using UV or X-ray irradiation (Fargeix, 1976; Reynaud, 1976) or lasers (Mims and McKinnell 1971) is difficult to apply to all the germinal crescent cells and leads to damage to the underlying tissues (Aige-Gil and Simkiss, 1991). As a result the chemical approach, using a chemosterilant such as 1,4-butanediol dimethane sulfonate (busulphan), has attracted increasing interest. (Aige-Gil and Simkiss, 1991; Hallett and Wentworth, 1991). This drug causes sterility in mammalian fetuses by destroying PGCs during their migratory phase (Hemsworth and Jackson, 1963). Similar effects have been reported for birds (Reynaud, 1977), although Swartz (1980) found that the drug was teratogenic when injected into the egg albumen. Our recent study avoided these effects by injecting busulphan into the yolk of domestic fowl eggs. Doses below $100 \mu \mathrm{g}$ per egg produced minimal abnormalities, while inducing up to $97 \%$ sterility (Aige-Gil and Simkiss, 1991). The following experiments were therefore undertaken to establish (i) the effect of increasing doses of busulphan on the number of germ cells in the ovary and testis (ii) the incidence of abnormal embryos and the percentage survival of these embryos (iii) whether busulphan permitted donor PGCs to settle in the treated gonad and (iv) how this affected the ratio of donor and recipient germ cells in chimaeric hatchlings and their offspring. 


\section{Materials and Methods}

\section{Animals}

White Leghorn birds from the line zero strain (Astrin et al, 1979) were used as recipients in all these experiments. An inbred strain of Rhode Island Red birds was used as a source of donor PGCs when required. The eggs were incubated in a forced air incubator at $37.5^{\circ} \mathrm{C}$ and $60 \%$ relative humidity and their development staged according to the scheme of Hamburger and Hamilton (1951).

\section{Treatments}

Busulphan (1,4-butanediol dimethane sulfonate; Sigma, Poole) was suspended in sesame oil. Eggs incubated for 0,24 , 48 and $72 \mathrm{~h}$ were injected with doses of $0,25,50$ or $250 \mu \mathrm{g}$ busulphan in $40 \mu \mathrm{l}$ sesame oil. Each dose was injected directly into the yolk through a hole in the egg (Aige-Gil and Simkiss, 1991) according to the method of Brunström and Örberg (1982). The hole in the eggshell was sealed with Micropore surgical tape (3M Health Care, Swansea) and the eggs returned to the incubator. The eggs were checked daily for viability by candling with a cold light source. Dead embryos were removed and their ages were recorded together with any visible abnormalities.

In a second experiment, doses of 0,50 and $250 \mu \mathrm{g}$ of busulphan in $40 \mu \mathrm{l}$ sesame oil were injected into eggs incubated for $24-30 \mathrm{~h}$. The eggs were incubated until day 16 when the embryos were killed, sexed and their gonads fixed in Bouin's fluid. They were embedded in paraffin wax, sectioned and stained with haematoxylin and eosin. The number of germ cells in five random sections of the testis or in the ovarian cortex were counted for each sample. The maximum thickness of the cortex of the ovary was also measured.

In a third experiment, a suspension of PGCs was prepared from germinal crescents of Rhode Island Red embryos at stages 5-11 of development using the method of Vick et al. (1993). White Leghorn embryos that had been injected with $50 \mu \mathrm{g}$ busulphan in sesame oil at $24 \mathrm{~h}$ incubation were incubated to stage 15 of development and injected with approximately $1 \mu$ l of Rhode Island Red PGC suspension. This was done by removing a small square window of eggshell from over the embryo and injecting into the vasculature with fine glass pipettes attached to a micromanipulator (Singer Instrument Co. Ltd., Watchet) and a microinjector (Narishige IM-5A/B, Tokyo). Post-operative eggs were sealed with Micropore tape and incubated normally. Twenty hatchlings from these experiments were raised to sexual maturity and six cocks were crossed with 12 hens on a $1: 2$ basis in six breeding groups. The first 20 eggs from each group were incubated and the chicks classified as pure white $(W L \times W L)$ spotted white $(R I R \times W L)$ or brown $(\mathrm{RIR} \times \mathrm{RIR})$.

\section{Results}

It is clear that the older the embryo at the time of injection of busulphan, the greater the survival (Table 1). Increasing the dose similarly decreases the number of embryos hatching. An
Table 1. Percentage survival of untreated control chick embryos $\dagger$ treated with $0,25,50$ or $250 \mu \mathrm{g}$ busulphan in $40 \mu \mathrm{l}$ sesame oil at $0,24,48$ or $72 \mathrm{~h}$ incubation

\begin{tabular}{lrlll}
\hline \multirow{2}{*}{$\begin{array}{l}\text { Time of } \\
\text { treatment } \\
\text { (h) }\end{array}$} & & \multicolumn{3}{c}{ Percentage surviving } \\
\cline { 3 - 5 } & $\begin{array}{c}\text { Dose } \\
(\mu \mathrm{g})\end{array}$ & 7 days & 15 days & Hatch \\
\hline 0 & & & & \\
& 0 & 65 & 59 & 46 \\
& 25 & 44 & 22 & 17 \\
& 50 & $40^{*}$ & $20^{*}$ & $10^{*}$ \\
24 & 250 & $30^{*}$ & $10^{*}$ & $0^{*}$ \\
& 0 & 70 & 70 & 58 \\
& 25 & 76 & 40 & 28 \\
48 & 50 & 76 & 44 & 26 \\
& 250 & 63 & 53 & 11 \\
& 0 & 81 & 68 & 47 \\
& 25 & 79 & 68 & 26 \\
72 & 50 & 75 & 56 & 44 \\
& 250 & 39 & 11 & 11 \\
& 0 & $87^{*}$ & $75^{*}$ & $71^{*}$ \\
& 25 & 86 & 76 & 52 \\
& 50 & $93^{*}$ & $64^{*}$ & $57^{*}$ \\
Untreated & 250 & 76 & 44 & 24 \\
& - & 92 & 91 & 84 \\
\hline
\end{tabular}

$t_{n}=16$ or more in all groups except those marked * where it was at least 10.

Table 2. Percentage of day 16 embryos $\dagger$ showing developmental abnormalities after they were injected with doses of $0,25,50$ or $250 \mu \mathrm{g}$ busulphan in $40 \mu \mathrm{l}$ sesame oil at 0,48 or $72 \mathrm{~h}$ incubation

\begin{tabular}{|c|c|c|c|c|}
\hline \multirow{2}{*}{$\begin{array}{l}\text { Time of } \\
\text { injection } \\
\text { (h) }\end{array}$} & \multicolumn{4}{|c|}{$\begin{array}{l}\text { Percentage of embryos } \\
\text { showing abnormalities } \\
\text { Busulphan }(\mu \mathrm{g})\end{array}$} \\
\hline & 0 & 25 & 50 & 250 \\
\hline 0 & 2 & 6 & $20^{*}$ & $60^{*}$ \\
\hline 48 & 0 & 0 & 19 & 50 \\
\hline 72 & $0^{*}$ & 0 & $0^{*}$ & $16^{*}$ \\
\hline
\end{tabular}

$\lceil n=16$ or more in all groups except those marked * where it was at least 10.

Table 3. Numbers of germ cells per $\mathrm{mm}^{2}$ in male and female gonads of day 16 embryos treated with doses of $0,25,50$ and $250 \mu \mathrm{g}$ busulphan in $40 \mu \mathrm{l}$ sesame oil at $24-30 \mathrm{~h}$ incubation

\begin{tabular}{lrccc}
\hline & \multicolumn{4}{c}{ Busulphan dose $(\mu \mathrm{g})$} \\
\cline { 2 - 5 } Sex & 0 & 25 & 50 & 250 \\
\hline Females & $1104 \pm 67$ & $721 \pm 52$ & $384 \pm 32$ & $41 \pm 9$ \\
Males & $465 \pm 33$ & $298 \pm 22$ & $170 \pm 11$ & $53 \pm 11$ \\
\hline
\end{tabular}

Values are means \pm SEM and all are significantly different at $P<0.001$. 

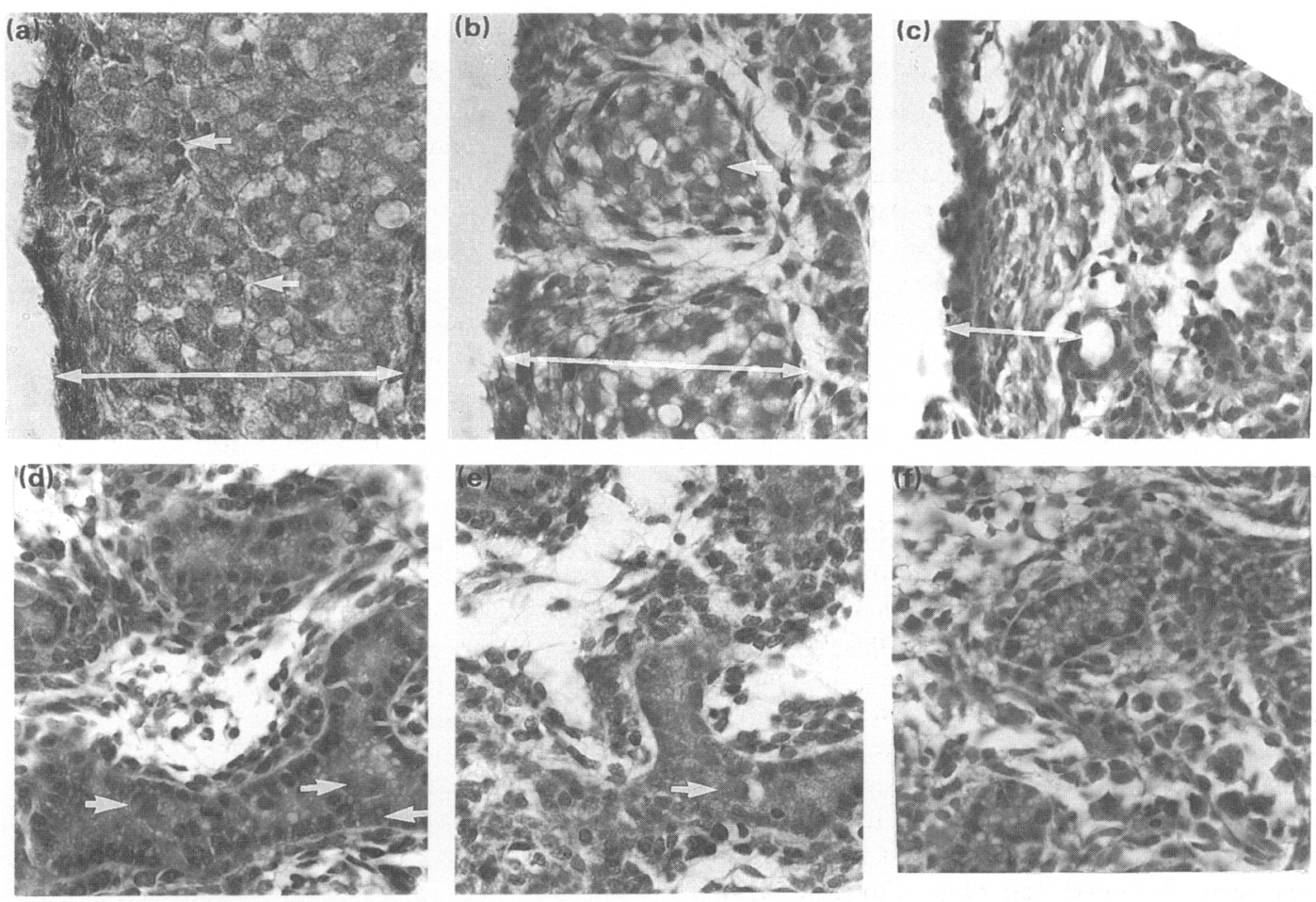

Fig. 1. Light micrographs of transverse sections of the left ovary of day 16 embryos; (a) controls, (b) treated with $50 \mu \mathrm{g}$ busulphan at $24-30 \mathrm{~h}$ incubation, (c) treated with $250 \mu \mathrm{g}$ busulphan at $24-30 \mathrm{~h}$ incubation. Note how the cortex is reduced in thickness (double headed line) and the clusters of primordial germ cells are reduced in size (arrows) following busulphan treatment. Transverse sections of testes are also shown for (d) control embryos, (e) testes after $50 \mu \mathrm{g}$ busulphan and ( $\mathrm{f}$ ) after $250 \mu \mathrm{g}$ busulphan was injected at $24-30 \mathrm{~h}$ incubation. Note how the busulphan reduces the number of seminiferous cords and decreases the number of germ cells within them (arrows). The overall size of the busulphan treated testes was smaller than those of controls. $\times 450$

Table 4. Numbers of hatchlings of various phenotypes in the first 20 hatchlings produced by crossing six male and 12 female germ-line chimaeras in six breeding groups

\begin{tabular}{llll}
\hline & \multicolumn{3}{c}{ Phenotypes of offspring-1 } \\
\cline { 2 - 4 } Group & White & White and spots & Brown \\
\hline 1 & 20 & 0 & 0 \\
2 & 20 & 0 & 0 \\
3 & 20 & 0 & 0 \\
4 & 17 & $3(15 \%)$ & 0 \\
5 & 15 & $5(25 \%)$ & 0 \\
6 & 11 & $9(45 \%)$ & 0 \\
\hline
\end{tabular}

White hatchlings are typical WL $\times W L$; white birds with spots are RIR $\times W L$ and go brown after three months; brown birds are RIR $\times$ RIR.

injection of sesame oil on its own caused some decrease in survival compared with survival values for untreated embryos.

The percentage of embryos showing developmental abnormalities increased with the dose of busulphan (Table 2). The most common abnormalities observed were abnormal limb buds in the form of pointed distal ends, haematomas and eye abnormalities, including microphthalmia. Embryos exposed to busulphan after 48 and $72 \mathrm{~h}$ incubation showed fewer terato- genic effects than younger specimens. All the control embryos that survived beyond day 5 were normal in appearance.

An analysis of the number of germ cells in histological sections of gonads of day 16 embryos (Table 3) showed significant differences $(P<0.001)$ in the effects of dose of busulphan. The thickness of the ovarian cortex was $86.0 \pm 4.2 \mu \mathrm{m}$ in control embryos, $54.3 \pm 4.4 \mu \mathrm{m}$ after $50 \mu \mathrm{g}$ and $31.9 \pm 1.4 \mu \mathrm{m}$ after $250 \mu \mathrm{g}$ busulphan (Fig. 1). The decrease in cortex thickness corresponds to an equivalent decline in the numbers of germ cells per unit area. In male embryos the testicular cords were reduced in size, contained few germ cells and were surrounded with extensive interstitial tissue as the dose of the drug was increased (Fig. 1).

The numbers of white, spotted and brown offspring from the busulphan White Leghorn-Rhode Island Red chimaeras are shown (Table 4).

\section{Discussion}

The stroma of the vertebrate gonad is derived from cells of the coelomic epithelium in which the primordial germ cells settle early in development. The interaction of these two quite separate cell lines has been studied in considerable detail. According to Dubois (1969) the germinal epithelium secretes a chemoattractant that causes the primordial germ cells to leave the vascular system and settle in the coelomic epithelium. 
Experiments by Kuwana $e$ t al. (1986) demonstrated this effect in culture and provide at least a partial explanation for the entry of the primordial germ cells into the definitive gonad tissue. Once within this epithelium there is a release from the mitotic block that appears to prevent primordial germ cells from dividing (Donovan et al., 1986), but experimental manipulations of these cell populations led Fargeix (1969) to propose that there was also autoregulation of these numbers. It is generally agreed that the sex of the germinal epithelium dictates whether the primordial germ cells will develop into spermatozoa or ova (Hajji et al., 1988). Thus germ cell settlement, their division, population size and differentiation all appear to depend upon an intimate interaction with the germinal epithelium.

The drug busulphan is a cytotoxic chemical that has been used extensively to treat myeloid leukaemia (Dunn, 1974). It also appears to affect stem cells and exerts a strong influence on migrating PGCs. Its sterilizing ability is well documented (Merchant, 1975; Reynaud, 1977), but when applied via the egg albumen it is also teratogenic. In this work small doses were injected into the yolk in a lipophilic solution. The drug then probably reaches the embryo via the subembryonic fluid which increases in volume until day 7 of incubation when it occupies about $25 \%$ of the total egg volume (Simkiss 1980). This rapid dilution of a small amount of the drug, which has a half-life of $10 \mathrm{~h}$ in the plasma and which is applied to a rapidly growing embryo probably results in a short pulse of busulphan which avoids the major teratological effects reported by Reynaud (1977) and Hallett and Wentworth (1991). Any teratological effects decrease with age of embryo at the time of application and large numbers of apparently normal hatchlings were obtained in our experiments by using doses of no more than $50 \mu \mathrm{g}$ per egg.

In a previous study, Aige-Gil and Simkiss (1990) treated $48 \mathrm{~h}$ embryos with $100 \mu \mathrm{g}$ busulphan in sesame oil and reduced the numbers of germ cells in day 6 embryos to approximately $5 \%$ of control values. Histological examination of the gonads of day 16 embryos treated with $50 \mu \mathrm{g}$ busulphan at $24-30 \mathrm{~h}$ shows that in these tissues the germ cell population has been reduced to about a third of control values. This result suggests that there may be some autoregulation of germ cell numbers as has been suggested previously by Fargeix (1976). Despite this, the cortex of the ovary was reduced in thickness in direct proportion to increasing dose and the germ cells formed progressively smaller clusters. In the males the testicular cords of busulphan-treated animals were reduced in number and contained fewer germ cells. Similar histological effects were noted by Reynaud $(1977,1981)$. It would appear, therefore, that a low dose of busulphan should increase the ratio of donor to endogenous PGCs i.e. $\left(N_{\mathrm{D}}: N_{\mathrm{R}}\right)$ at least threefold in chimaeric birds.

It has recently been shown that transgenic birds can be produced by introducing foreign DNA into the PGCs that are used to make germ-line chimaeras (Vick et al., 1993) so that the use of busulphan could increase the efficiency of this procedure. Before that can be done, however, it is necessary to show that the pulse of busulphan that is used to destroy the endogenous PGCs has disappeared before the donor PGCs are introduced. Clearly the time of the injections and the dose used are critical if they are not to destroy the donor PGCs as well as the endogenous cells. It is also clear that the germinal ridge that receives the
PGCs must not be damaged (Reynaud, 1981). Obviously if the sterilizing effect of busulphan was mediated by blocking the settlement of the PGCs in the definitive gonad then both endogenous and donor cells would be excluded.

The experiments using PGCs from Rhode Island Red and White Leghorn birds produced chimaeras that enabled these possibilities to be investigated. These results show that all these birds were fertile, unlike the sterile ones produced by Reynaud (1981) who used much larger doses of busulphan. Of the six breeding groups set up, three produced only White Leghorn offspring, indicating either that none of the Rhode Island Red PGCs had been successfully transferred or that they had not been successful in producing fertilized eggs. The other three groups produced an average of $72 \%$ White Leghorn $(\mathrm{WL} \times \mathrm{WL})$ and $28 \%$ Rhode Island Red (RIR $\times \mathrm{WL}$ ) crosses. For any individual parent that suggests an average of $14 \%$ Rhode Island Red gametes or presumably one donor PGC for every six recipient PGCs. Our previous work in breeding from chimaeras that had not been partially sterilized with busulphan gave success rates of less than $4 \%$ (Vick et al., 1993). It is concluded, therefore, that when used in small doses and at the right time busulphan will partially sterilize a chick embryo and increase the relative number of donor PGCs in the germ-line chimaera. In the study reported here both the histological effects and the breeding experiments suggest a roughly threefold reduction in the number of endogenous PGCs in the treated animals.

The results reported in these experiments are in complete contrast to those obtained by Petitte et al. (1991). They produced 59 birds which they had attempted to make into germ-line chimaeras by transferring PGCs from White Leghorn embryos into Barred Plymouth Rock recipients. They raised 3117 offspring from these birds without finding any evidence for the effective transfer of primordial germ cells into a germline chimaera, whereas by our technique we would have expected to produce 436 positives from these numbers. This difference in results is probably due to a number of technical differences. First, Pettite et al. used bloodborne PGCs, whereas much better samples of these cells are obtained from germinal crescent preparations. Second, there must be some doubt about their experimental manipulations, both in terms of the age of the embryos they used and the sites and effectiveness of their injections. We attribute our $50 \%$ failure rate to these types of difficulty, although it is equally likely that transfer of PGCs between the sexes may account for these results.

The results from these experiments indicate that a large increase in germ-line chimaerism can be achieved by the use of a partial chemosterilant such as busulphan. This technique may be of considerable value in increasing the efficiency of producing transgenic birds by transferring transformed PGCs (Vick et al., 1993) and in understanding the interactions between these cells and the germinal ridge.

This work was supported by grants from the Agriculture and Food Research Council and Merck, Sharp \& Dohme Research Laboratories.

\section{References}

Aige-Gil V and Simkiss K (1991) Sterilisation of avian embryos with busulphan Research in Veterinary Science 50 139-144 
Astrin SM, Buss EG and Hayward WS (1979) Endogenous viral genes are non-essential in the chicken Nature 282 339-341

Brunström B and Orberg J (1982) A method for studying embryo toxicity of lipophitic substances experimentally introduced into hen's eggs Ambio 11 209-211

Donovan PJ, Stott D, Cairns LA, Heasman J and Wylie CC (1986) Migratory and postmigratory mouse primordial germ cells behave differently in culture Cell $44831-838$

Dubois R (1969) Le mécanisme d'entrée des cellules germinales primordiales dans le réseau vasculaire chez l'embryon de poulet journal of Embryology and Experimental Morphology 21 255-270

Dunn CDR (1974) The chemical and biological properties of Busulphan (Myleran) Experimental Haematology 2 101-117

Fargeix N (1969) Les cellules germinales du canard chez des embryons normaux et des embryons de regulation. Étude des jeunes stades du développement Joumal of Embryology and Experimental Morphology 22 477-503

Fargeix N (1976) Régulation du nombre des gonocytes dans les ébauches gonadiques de l'embryon de canard après destruction partielle du stock initial des cellules germinales Comptes Rendus de l'Académie des Sciences (Paris) 282 305-308

Hajji K, Martin C, Perrimon A and Dieterlen-Lievre $\mathbf{F}$ (1988) The sexual phenotype of avian chimaeric gonads with germinal and stromal cells of opposite genetic sexes Biological Structures and Morphogenesis 1 107-116

Hallett JS and Wentworth BC (1991) The effects of busulphan on gonadal differentiation and development in Japanese quail (Coturnix coturnix japonica) Poultry Science 70 1619-1623

Hamburger $V$ and Hamilton $H$ (1951) A series of normal stages in the development of the chick embryo Joumal of Morphology 88 49-92

Hemsworth BH and Jackson H (1963) Effect of busulphan on the developing ovary in the rat Journal of Reproduction and Fertility $6229-233$

Kuwana T, Maeda-Suga H and Fujimoto T (1986) Attraction of chick primordial germ cells by gonadal anlage in vitro Anatomical Record $215403-406$

McCarrey JR and Abbott UK (1982) Functional differentiation of chick gonads following depletion of primordial germ cells Joumal of Embryology and Experimental Morphology 68 161-174

Merchant H (1975) Rat gonadal and ovarian organogenesis with and without germ cells. An ultrastructural study Developmental Biology 44 1-21

Mims MF and McKinnell RG (1971) Laser irradiation of the chick embryo germinal crescent Journal of Embryology and Experimental Morphology 26 $31-36$
Palmiter RD, Brinster RL, Hammer RE, Trumbauer ME, Rosenfeld MG, Birnberg NC and Evans RM (1982) Dramatic growth of mice that develop from eggs micro-injected with metallothionein-growth hormone fusion genes Nature $300611-615$

Petitte JN, Clarke ME, Liu G, Verrinder Gibbins A and Etches RJ (1990) Production of somatic and germline chimaeras in the chicken by transfer of early blastodermal cells Development 108 185-189

Petitte JN, Clark ME and Etches RJ (1991) Assessment of functional gametes in chickens after transfer of primordial germ cells journal of Reproduction and Fertility 92 225-229

Reynaud G (1976) Étude de la localisation des cellules germinales primordiales chez l'embryon de caille japonaise au moyen d'une technique d'irradiation aux rayons ultraviolets Comptes Rendus de l'Académie des Sciences (Paris) $\mathbf{2 8 2}$ $1195-1198$

Reynaud G (1977) Action du Busulphan sur la lignée germinale de l'embryon de poulet Bulletin de la Société Zoologique de France 102 417-429

Reynaud G (1981) The effect of busulphan on the germ line of the quail embryo Archives d'Anatomie Microscopique et de Morphologie Experimentale $\mathbf{7 0}$ $25 \mathrm{I}-258$

Sang $H$ and Perry M (1989) Episomal replication of cloned DNA injected into the fertilised ovum of the hen, Gallus domesticus Molecular Reproduction and Development 1 98-106

Savva D, Page N, Vick L and Simkiss K (1991) Detection of foreign DNA in transgenic chicken embryos using the polymerase chain reaction Research in Veterinary Science 50 131-133

Simkiss K (1980) Water and ionic fluxes inside the egg American Zoologist 20 385-393

Simkiss K, Rowlett K, Bumstead N and Freeman BM (1989) Transfer of primordial germ cell DNA between embryos Protoplasma 151 164-166

Simkiss K, Vick L, Luke G, Page N and Savva D (1990) Infection of primordial germ cells with defective retroviruses and their transfer to the developing embryo Proceedings of the 4th World Congress on Genetics Applied to Livestock Production Edinburgh XVI 111-114

Swartz WJ (1980) Response of early chick embryos to Busulphan Teratology 21 $1-8$

Vick L, Li Y and Simkiss K (1993) Transgenic birds from transformed primordial germ cells Proceedings of the Royal Society, London 251 179-182 